\title{
Sustaining Work Participation Across the Life Course
}

\author{
Glenn S. Pransky ${ }^{1,2}$ (D) Jean-Baptise Fassier ${ }^{5} \cdot$ Elyssa Besen $^{1} \cdot$ Peter Blanck $^{3}$.

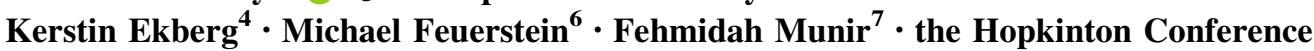 \\ Working Group on Workplace Disability Prevention
}

Published online: 4 October 2016

(C) The Author(s) 2016. This article is published with open access at Springerlink.com

\begin{abstract}
Introduction Many disability prevention strategies are focused on acute injuries and brief illness episodes, but there will be growing challenges for employers to manage circumstances of recurrent, chronic, or fluctuating symptoms in an aging workforce. The goal of this article is to summarize existing peer-review research in this area, compare this with employer discourse in the grey literature, and recommend future research priorities. Methods The authors participated in a year-long sponsored collaboration that ultimately led to an invited 3-day conference, "Improving Research of Employer Practices to Prevent Disability", held October 14-16, 2015, in Hopkinton, Massachusetts, USA. The collaboration included a topical review of the scientific and industry literature, group discussion to identify key areas and challenges, drafting of
\end{abstract}

The opinions and assertions contained herein are the private views of the authors and are not to be construed as being official or as reflecting the views of the Uniformed Services University of the Health Sciences or the Department of Defense.

Glenn S. Pransky

glenn.pransky@libertymutual.com

1 Liberty Mutual Research Institute for Safety, 71 Frankland Road, Hopkinton, MA 01748, USA

2 University of Massachusetts Medical School, Worcester, MA, USA

3 Burton Blatt Institute, Syracuse University, Syracuse, NY, USA

4 Linköping University, Linköping, Sweden

5 Claude Bernard University Lyon 1, Lyon, France

6 Uniformed Services University of the Health Sciences, Bethesda, MD, USA

7 University of Loughborough, Leicester, UK initial documents, and feedback from peer researchers and a special panel of experts with employer experience. $R e$ sults Cancer and mental illness were chosen as examples of chronic or recurring conditions that might challenge conventional workplace return-to-work practices. Workplace problems identified in the literature included fatigue, emotional exhaustion, poor supervisor and co-worker support, stigma, discrimination, and difficulties finding appropriate accommodations. Workplace intervention research is generally lacking, but there is preliminary support for improving workplace self-management strategies, collaborative problem-solving, and providing checklists and other tools for job accommodation, ideas echoed in the literature directed toward employers. Research might be improved by following workers from an earlier stage of developing workplace concerns. Conclusions Future research of work disability should focus on earlier identification of at-risk workers with chronic conditions, the use of more innovative and flexible accommodation strategies matched to specific functional losses, stronger integration of the workplace into on-going rehabilitation efforts, and a better understanding of stigma and other social factors at work.

Keywords Chronic health conditions - Employer practices Cancer $\cdot$ Mental health

\section{Introduction}

One profound demographic shift facing many industrialized nations is the increasing longevity and average age of the population. As the population ages, the available workforce is also aging. By 2020, at least quarter of the workforce in many countries is expected to be age 55 and 
older [1]. At the same time, chronic health conditions are becoming increasingly important as a cause of work disability across the globe, affecting not only aging workers, but also youth in transition, and mid-career workers. Over $40 \%$ of US workers have a chronic health condition and $15-20 \%$ of workers report health-related work limitations; studies in European countries yield similar results [2]. These shifts in the age and fitness of workers are likely to influence employer practices to manage and prevent disability.

Research of employer practices and their impact on health and disability may be improved by adopting a lifecourse perspective on employee health and disability. A life-course view examines how chronological age, changing relationships, life transitions, social and occupation development shape people's lives from birth to death [3]. This perspective creates an opportunity to examine how the impact of workplace factors and workplace responses to work disability might differ depending on the age and career stage of a worker, and where particular workplace WDP approaches may be more important.

Although some work disability problems observed in aging workers are primarily related to health, other factorssuch as competing retirement options, career status, likelihood of accommodations and mobility in the workforceare specific to age group and career stage, and can interact with health [3]. Economic, social and demographic changes have led to an increased need to include more older workers in the workforce, and to find ways to better enable workers with health conditions to maintain employment [4]. This direction is supported by new legislation that seeks to support the rights and ability to work of persons with potentially disabling conditions, as exemplified by the UN Convention of the Rights of Persons with Disabilities (CRPD), stating that workers with disabilities have an equal opportunity to employment [5]. The rights of disabled people set out in the CRPD presently are recognized by more than one hundred and fifty nations who ratified the treaty [5]. These developments all suggest the need for more information on how workplace factors and related interventions can better support the employment of persons with various health conditions, across the life-course.

There are fundamental principles and effective strategies for work disability prevention (WDP) that appear to be common across health conditions and work situations, and are consistent with the goals of the CRPD. Some of these principles and strategies include providing appropriate health care, establishing workers' ability to do meaningful work, promoting employer responsiveness, and offering job accommodations [6]. However, most research on workplace issues and WDP has focused on musculoskeletal disorders and work injuries, there is less evidence for generalization of these principles across other types of health conditions [7]. Our objective was to identify relevant scientific research and current employer practices for managing chronic health conditions and related work disability in the workplace, as a basis for recommendations for improving future research of employer disability prevention strategies.

\section{Methods}

The authors participated in an invited 3-day conference, "Improving Research of Employer Practices to Prevent Disability", held October 14-16, 2015, in Hopkinton, Massachusetts, USA. Methods and general proceedings of the conference are described in the introductory article to this special issue [8]. The authors of this article represented a sub-group tasked with understanding the state of the science with respect to employer practices for managing the increasing prevalence of chronic health conditions and workplace efforts to prevent this source of disability through job accommodation and support, through a lifecourse view of employment and disability. We contrast key conceptual and theoretical frameworks, review the applicable scientific literature, assess its impact for employer decision-making, and compare recommendations with that of the employer-directed grey literature. These observations and recommendations are useful for areas that have not been thoroughly investigated. We recommend future research priorities, based on important scientific gaps. Two chronic health conditions with divergent prevalence across the life span-mental disorders [9] and cancer [10]—were chosen as exemplars to illustrate key principles that may apply across a range of conditions.

\section{Results}

\section{Aging and Chronic Illness in the Workplace}

As a result of decreasing fertility and mortality rates, coupled with increasing life expectancy, the percentage of the world's population age 60 years and older is expected to increase from $9.2 \%$ in 1990 to $21.1 \%$ by 2050 [11]. In OECD countries, the labor force participation rate of workers ages 55-64 years has increased from $47.7 \%$ in 1990 to $55.6 \%$ by 2012 [12]. Although there are significant differences by country, retirement ages are gradually increasing in most established economies. In older workers, chronological age may be inconsistent with career stage and status. Some older workers may be nearing retirement, and others are already in post-retirement careers, and thus may have very different work disability considerations. Post-retirement workers may have lower job attachment, 
less financial or personal need to return to work after a disabling illness, and may be more interested in exploring alternative employment-especially if the job is perceived as a poor match for their capabilities. Older workers may want to stay at work for the benefits of social engagement and discretionary income. In many countries, employers need these workers, and are especially interested in capturing their expertise and maturity [13]. However, the growth of an aging workforce has heightened employer concerns about the ability of older workers to remain at work given their higher rate of medical illness, and increased risk for work disability [10, 14].

\section{Impact of Chronic Health Conditions in the Workplace}

Chronic health conditions-including obesity, diabetes, mental disorders, cancer, arthritis, and lung, gastrointestinal and cardiovascular diseases-account for considerable work disability (WD), and reduced productivity on the job $[15,16]$. Their prevalence in the workforce is changing for several reasons. Advances in medical care is converting mortality to morbidity. Workers with chronic illness have fewer resources enabling them to retire, and the impacts of a sedentary lifestyle are becoming more manifest in older workers [17]. Many workers with chronic illness have multiple comorbidities or simultaneous conditions, challenging traditional views of a single disease as a cause of work disability, and are therefore at higher risk of frequent or prolonged work absence [18].

Several studies have examined the specific challenges that workers with chronic health conditions face at work, that place them at risk for low productivity or WD. These problems include fatigue, emotional exhaustion, inconsistent support from colleagues and supervisors, and difficulty modifying their jobs to match their capabilities [19]. With serious chronic illness, medication adherence and side-effects can be additional risk factors for lower productivity and work absence [20]. Although stigma has been primarily associated with mental illness, the problem of stigma and discrimination at work is reported across a range of chronic conditions, and interventions to educate employers and co-workers are a major emphasis of condition-specific advocacy groups for diabetes, lung disease, cancer and other conditions.

Research has shown that while older workers are not at an increased risk for a work-disabling injury [10, 21], when one does occur, older workers frequently sustain more serious injuries than younger workers, they take longer to RTW, are more likely to leave work again after attempting to RTW, and have a higher chance of never achieving a successful RTW [14, 22] Work disability claims for older workers tend to be more costly than for younger workers [23], adding further concerns for employers.
Interventions to Promote Retention and Productivity

The traditional workplace approach to address work disability and chronic illness focuses on health improvement, disease management, in systems directed by legal requirements, administrative structures, diagnostic classifications, and specific rules [23]. Despite the inverse relationship between age and positive RTW outcomes, there have been relatively few workplace interventions to improve RTW targeting older workers (pre or post retirement) on those with chronic illness of any age. It is well known that employer attitudes, organizational culture and support play a critical role in older workers' RTW [24], but these factors have not been evaluated in comparative trials. For example, employer responses to work-related and nonwork related conditions are often different, with respect to inquiry about causation, concerns about liability, case management practices, and nature of accommodations to facilitate return to work [25]. Condition-specific employment advocacy groups promote strategies to support employment of younger workers with chronic health conditions, but these lack empirical evidence of where and when they are helpful or effective.

\section{Fitness and Wellness Programs}

Although frequently advocated in the professional literature, general workplace fitness and lifestyle programs have limited impact on WD rates [23, 26], even those targeting physical activity and fitness as a way of decreasing sickness-related absence [27]. These wellness programs usually fail to engage those who could most benefit, and few have documented long-term sustained health benefits in large numbers of enrollees. For example, one workplace intervention involved exercise, coaching related to vitality, and healthy eating, targeting workers over the age of 65 [28], and was not found to be cost-effective. In contrast, an intervention involving food industry workers aged 55 and older aimed at maintaining well-being and work status found that absenteeism of 21 days or longer was decreased [29]. Another study involving female nurses age 49 or older, found that a Tai Chi workplace intervention reduced perceived work limitations compared to no intervention [30].

\section{Medical Case Management}

Diagnosis_-based medical case management that focuses primarily on improving clinical care and compliance, without substantial integration of workplace issues, is generally not effective in preventing work disability or improving RTW [31, 32]. This approach fails to take into account the wide variation in work ability within a single 
diagnosis, and nonmedical (including workplace) factors that primarily determine RTW outcomes. There are a few exceptions-for example, screening and initiating treatment for an untreated, severe, and potentially-disabling condition (e.g., major depression or untreated diabetes) that has already resulted in significant functional impairment does improve WD outcomes [33].

\section{Identifying Workers at Greatest Risk of Disability}

There are a few examples of individualized, workplacebased programs that do effectively target WD risk. For example, Kant, Jansen et al [34] describe an intervention at a large Dutch bank, where risk for WD was identified through a screening tool, and high-risk persons were referred to an occupational physician for consultation, development of a personalized program to address workplace and individual risk factors, and follow-up. Compared to controls, the intervention group had 13 (about $30 \%$ ) fewer lost work days. About half of the participants had a chronic illness (cardiovascular, musculoskeletal, and other conditions), although results were not reported for this group separately. An intervention that addressed lifestyle and work in a comprehensive, individualized manner, involving the workplace, for persons with diabetes and obesity, had a significant impact on lost work days in a randomized trial [35]. A similar trial, with occupational physician consultation for workers at high risk for future (sickness absence), was reported in 2008 by Taimela et al [36]; although this study also included a significant number of workers with chronic health conditions (besides mental health problems), the exact numbers or effectiveness of the intervention with this subset was not reported. Together, these studies reinforce the value of an individualized workplace approach to sickness absence, taking into account the person, condition, and workplace, and addressing these aspects in an integrated manner. However, these studies have a clinical focus, and don't change the workplace in a more fundamental way. There are no comparable scientific workplace studies of workers focusing on an individualized approach at either end of the age spectrum.

\section{Strategies to Minimize Impact of Chronic Illness on Work}

Studies of workers with chronic illness who are successful on the job, despite serious health problems suggest new strategies that may be effective. Workers with chronic pain reported that modifying work activities and routines, reducing pain symptoms, using cognitive strategies and communicating effectively about pain were important. Six predominant themes emerged: knowing your work setting, talking about pain, being prepared for a bad day, thoughts and emotions, keeping moving and finding leeway [37]. In another study, success factors were categorized into five themes: personal characteristics, adjustment latitude, coping with pain, use of healthcare services, and pain beliefs [38]. Studies of workers with chronic medical conditions identify supervisor support and ability to modify work as key factors [39]. In one study, employer representatives identified workplace factors that were most important in supporting continued employment for workers with chronic illness. Line managers focused on employer/employee cooperation as most important, whereas human resource managers focused more on the importance of organizational policy and culture related to working with a health condition [40].

Recently, interventions based on these observations have attempted to enhance worker self-management and supervisor support in the workplace. Results so far have indicated improved self-efficacy for staying at work, but no significant impact on RTW or work retention [41]. Another approach has focused on improving support in the workplace, through trained supervisors or a non-medical peer advocate, who provide reassurance, facilitate accommodations, and problem-solving. This strategy has been successful in decreasing work absence due to musculoskeletal pain, minor mental health conditions (anxiety) and minor gastrointestinal problems [42]. As accommodations are an essential component of work disability prevention in workers with chronic illness [43], workplaces are experimenting with a bottom-up non-medical strategy for workplace accommodations. In these models, employees and their supervisors have the primary responsibility for figuring out accommodations; grey literature reports cite greatly improved work absence outcomes [44]. Workplace DM policies and programs also struggle with intermittent work absence that can occur because of chronic illnesses, and generally focus on the administrative complexities of managing entitlements such as sick leave benefits, rather than the opportunity for coordinating medical care and workplace accommodation. As the functional impacts of chronic illness can vary greatly over time, an employeedriven approach may offer a more flexible and responsive solution than requesting a formal accommodation each time there is a change in health and functional ability, as long as the accommodations are reasonable for both employer and employee.

There has also been some effort to examine whether workplace interventions may be more effective at different ages. One study of individuals participating in a workplace intervention aimed at increasing RTW after taking sickleave as a result of burnout showed that the intervention was only effective for younger workers (under 45.5 years of age) [45]. Another intervention aimed at improving RTW following low back pain was only effective for older workers [46]. Other studies examined potential age 
differences in the effectiveness of interventions but did not find differences based on participants' ages [26].

\section{Cancer and Work}

Cancer is one of the leading causes of morbidity and mortality worldwide. It is estimated that about $40 \%$ of all cancer patients are diagnosed between ages 15 and 64 years, when work life plays a significant role [47]. Surviving cancer can lead to new challenges with regard to work. Many employees diagnosed and treated for cancer are interested in returning or remaining at work. This section provides a summary of cancer survivors and work in order to illustrate the current evidence related to this health problem at work. This section also addresses some of the age related concerns because as with most chronic health problems, cancer and its treatment can impact many different age groups of future and current employees.

\section{Cancer and Return to Work}

As with other serious health problems the first of these challenges is returning to work during or following cancer treatment. The evidence across studies suggests that an average of $63.5 \%$ of cancer survivors do return to work [48].). However, return-to-work rates among cancer survivors vary from 24 to $94 \%$, depending on the type and stage of cancer and the treatment regime [48, 49]; comorbidity [50]; and perceptions of work ability [51]. The time taken to return to work also varies significantly with around $40 \%$ returning to work by 6 months post diagnosis to around $89 \%$ returning by 24 months post diagnosis [48]. The rate of recovery of cognitive work ability is gradual, highly variable, and can take years in some cases, although full recovery is often possible [52].

While return to work also varies by type of sick leave or national policy [53], unemployment remains a significant risk factor among cancer survivors [54]. Though the specific reasons for leaving the workplace were not clearly identified, a recent a review by Mehnert [48] found that between 26 and $53 \%$ of cancer survivors either lost their job or left their job over a 72-month period post diagnosis although between 23 and $75 \%$ of those were re-employed. Those recovering from breast and lung cancer are at higher risk of unemployment or reduced labour force participation [55]. These figures suggest that while the majority of cancer survivors do eventually return to work, remaining at work may pose a greater challenge [56].

\section{Work Retention After Cancer}

A number of long-term and late effects of cancer or its treatment have been related to poor work outcomes including work retention among cancer survivors. These include fatigue, physical and cognitive problems [57], and decreased mental and physical work ability [58]. Accordingly, there has been a focus across a number of countries on raising awareness among employers on the impact of cancer and its treatment upon employees [59, 60], and several conceptual models of cancer and work have been developed (Table 1).

Cancer survivors are more likely to be employed if they perceived their employer as accommodating, received support from their colleagues and line manager and had a good relationship with their employer/line manager [53, 61]. Another contributing factor to good work outcomes are actual work adjustments or accommodations. A study by Torp et al [58] found that slightly over a quarter of employed cancer survivors had work adjustments made such as reducing/changing the number of hours worked per week and changes to work tasks which enabled them to continue working.

Poorer work retention (i.e., cancer survivors changing jobs) among cancer survivors has been related to job discrimination [62]. In the US, when the workplace is perceived as creating an atmosphere where forms of discrimination related to work ability are alleged, an employee has a right to file a claim for employment discrimination (under the Americans with Disabilities Act). A study by Feuerstein et al [60] found that cancer survivors are more likely to file claims related to job loss or differential treatment by workplace policies than other chronic illness groups. Lack of understanding or support from supervisors affecting the work ability of cancer survivors has also been reported [63]. A UK study found wide diversity among organizations in their capacity to offer flexible arrangements and some employers failed to make adequate provisions for cancer survivors due to their lack of awareness regarding the needs of employees diagnosed with cancer [51]. Other factors associated with poor work ability and actual work retention were high job demands, and lack of promotion or career progression due to cancer $[53,58]$.

\section{Workplace Based Interventions}

To date, there is a paucity of workplace-based interventions specifically for those diagnosed and treated with cancer [64]. Munir et al [65] developed a behavior checklist to help supervisors return cancer survivors back to work. However, while anecdotal data suggest it is helpful and download data suggests people are interested in looking at the checklist, it has not been empirically tested for effectiveness. Munir et al [66] also developed a work selfmanagement tool to be used by cancer survivors with their employers to identify needed workplace adjustments and 
Table 1 Conceptual models of cancer and work outcomes from the scientific literature

\begin{tabular}{|c|c|c|c|c|c|}
\hline Author & Direct factors & Indirect factors & Mediating factors & Moderating factors & Outcome measures \\
\hline Chow [91] & $\begin{array}{l}\text { Financial pressure; } \\
\text { health insurance; } \\
\text { socio- } \\
\text { demographic } \\
\text { factors }\end{array}$ & $\begin{array}{l}\text { Health status; personal } \\
\text { factors and beliefs; } \\
\text { environmental and } \\
\text { workplace factors }\end{array}$ & $\begin{array}{l}\text { Physical and mental work } \\
\text { demands; physical and } \\
\text { mental work ability }\end{array}$ & $\begin{array}{l}\text { Physical and mental } \\
\text { work demands } \\
\text { interact with } \\
\text { physical and mental } \\
\text { work ability }\end{array}$ & Return to work \\
\hline $\begin{array}{l}\text { Feuerstein } \\
\text { [92] }\end{array}$ & $\begin{array}{l}\text { Work } \\
\text { environment; } \\
\text { work demands; } \\
\text { policies and } \\
\text { procedures; } \\
\text { economic factors }\end{array}$ & $\begin{array}{l}\text { Health and wellbeing, } \\
\text { symptoms }\end{array}$ & $\begin{array}{l}\text { Work environment; } \\
\text { policies and procedures; } \\
\text { economic factors }\end{array}$ & $\begin{array}{l}\text { Health and wellbeing } \\
\text { interacts with } \\
\text { symptoms; } \\
\text { functional status } \\
\text { interacts with work } \\
\text { demands }\end{array}$ & $\begin{array}{l}\text { Return to work, work } \\
\text { ability, work performance } \\
\text { sustainability (work } \\
\text { retention) }\end{array}$ \\
\hline $\begin{array}{l}\text { Mehnert } \\
\text { [48] }\end{array}$ & $\begin{array}{l}\text { Disease specific } \\
\text { factors; treatment } \\
\text { related factors }\end{array}$ & $\begin{array}{l}\text { Disease specific } \\
\text { factors; treatment } \\
\text { related factors }\end{array}$ & $\begin{array}{l}\text { Demographic factors; } \\
\text { impairments; health } \\
\text { status; psychosocial and } \\
\text { motivational factors; } \\
\text { work-related factors and } \\
\text { interventions }\end{array}$ & Not described & $\begin{array}{l}\text { Employment status; return- } \\
\text { to-work; work ability; sick } \\
\text { leave and duration; work } \\
\text { changes; productivity; } \\
\text { disability }\end{array}$ \\
\hline $\begin{array}{l}\text { Mehnert } \\
\text { [48] }\end{array}$ & $\begin{array}{l}\text { Interventions and } \\
\text { rehabilitation } \\
\text { programs } \\
\text { promoting return } \\
\text { to work and } \\
\text { employment }\end{array}$ & $\begin{array}{l}\text { Individual and } \\
\text { interpersonal factors; } \\
\text { short-term, long- } \\
\text { term, and late effects } \\
\text { of cancer and cancer } \\
\text { treatments }\end{array}$ & $\begin{array}{l}\text { Interventions and } \\
\text { rehabilitation programs } \\
\text { promoting return to work } \\
\text { and employment }\end{array}$ & $\begin{array}{l}\text { Individual and } \\
\text { interpersonal factors; } \\
\text { short-term, long- } \\
\text { term, and late effects } \\
\text { of cancer and cancer } \\
\text { treatments }\end{array}$ & $\begin{array}{l}\text { Employment/return to } \\
\text { work; work ability; work } \\
\text { performance; job } \\
\text { opportunities; income; } \\
\text { work satisfaction; job } \\
\text { promotion and training; } \\
\text { sustainability }\end{array}$ \\
\hline $\begin{array}{l}\text { Steiner } \\
\text { [93] }\end{array}$ & $\begin{array}{l}\text { Individual } \\
\text { characteristics; } \\
\text { general health } \\
\text { perceptions; } \\
\text { characteristics of } \\
\text { work } \\
\text { environment }\end{array}$ & $\begin{array}{l}\text { Cancer and health } \\
\text { status; symptoms; } \\
\text { functional status }\end{array}$ & $\begin{array}{l}\text { Health status; symptoms; } \\
\text { functional status }\end{array}$ & Not described & $\begin{array}{l}\text { Work status; job changes; } \\
\text { work and role content; } \\
\text { economic status; job } \\
\text { satisfaction }\end{array}$ \\
\hline
\end{tabular}

support. While promising, these new tools need to be studied to determine their effectiveness. Two research protocols currently in progress $[67,68]$ focus on return to work in cancer and involve the workplace.

\section{Mental Health Conditions and Work}

Most people with mental ill-health are affected by mild-tomoderate illness-predominantly mood and anxiety disorders, commonly referred to as "common mental illness". According to the Global Burden of Diseases Study, mental disorders and substance abuse were the chief causes of years lived with disability (175 million years worldwide in 2010) [69]. In the European Union, the estimated total costs of mental illness were around $3.5 \%$ of GDP in 2010, with similar estimates for developed non-European countries [70]. Mental ill-health affects one-fifth of the workingage population at any given moment [70]. In the US, a survey found a total of $6.4 \%$ of employed respondents had a major depressive disorder episode in the past 12 months, and an additional $1.1 \%$ had major depressive episodes due to bipolar disorder or mania-hypomania [71].
In OECD countries, mental ill-health is responsible for between one-third and one-half of all long-term sickness and disability among the working-age population [70]. In the US, $36 \%$ of Social Security Disability Insurance (SSDI) and $60 \%$ of working-age Supplemental Security Income (SSI) beneficiaries have a mental illness as their primary reason for inability to work [72]. Relative to the mentally healthy, the employment rate of people who suffer from poor mental health is 15-30\% lower and their unemployment compensation rate is twice as high [73]. Co-morbidity of back pain and common mental disorders is associated with a higher risk of disability pension than either individual condition, when added up [74].

In the workplace, mental ill-health has a greater financial impact due to low productivity at work than work absence. Approximately $30 \%$ of lost work productivity due to depression in the US workforce is attributable to absenteeism, but $70 \%$ is attributable to presenteeism [71]. For major depressive disorders (MDD), annualized estimates are 225 million lost workdays and $\$ 36.6$ billion lost productivity per year in the US [71]. 


\section{Mental Health and the Work Environment}

Although work is a generally protective environment and fosters good mental health [75], it can also cause distress for certain employees and exacerbate mental health conditions [73]. Poor-quality jobs, problematic leadership, and psychosocial stress in the workplace can put the psychological health of the worker under strain and even trigger specific mental health conditions [76]. In the EU, high psychological demands, discrimination, bullying, and work-life imbalance have been observed as risk factors for sickness absence onset [77].

As with other chronic conditions, cause-and-effect relationships between the work environment and mental health are complex and multi-directional. On the one hand, poor psychosocial work environment can cause mental illhealth. On the other hand, workers with mental health problems tend to work in lower-quality jobs and environments, earn less per hour, have less secure jobs, are less satisfied with their jobs, report strain more often, and perceive their work situation more negatively [73]. The importance of psychosocial hazards in the work environment has been acknowledged by many countries through labor legislation requiring employers to routinely assess, prevent and control psychosocial risks at work. However, employers may consider the incentives for reducing psychosocial workplace risks as less compelling than for general workplace risks. Many enterprises, especially most small enterprises, receive minimal support or incentives to address psychosocial risks.

\section{Interventions to Promote Return to Work and Work Retention}

A wide range of interventions with a focus at the individual (worker), organizational (workplace), system (healthcare) level, or in combination have been developed and evaluated. A typology of these interventions is presented in Table 2. The nature of workplace involvement is often difficult to determine in these studies (being the place of delivery, the operator-facilitator and/or the target of the intervention). Even when interventions are indicated as workplace-based or oriented, most are in fact individually targeted [78-81].

Several systematic reviews attempted to synthetize the evidence from original studies, but the heterogeneity of interventions and outcomes precludes any single conclusion (Table 3). For example, a Cochrane systematic review [80] identified 5 workplace-based interventions intended to promote return to work for workers will mental ill-health [82-86], which demonstrated a significant improvement in time until first RTW (HR 2.64, $95 \%$ CI 1.41-4.95), but no impact on sustained RTW (HR 0.79, 95 \% CI 0.54-1.17).
All studies had been conducted in the Netherlands. Two main components of these interventions are worth mentioning. Firstly, a cognitive perspective of the RTW process was adopted, with the provision of a psychoeducational component including empowerment, problem resolution skills and self-help competencies. Secondly, a collaborative / participative approach was adopted, aiming at achieving a consensus between the supervisor and the worker about work accommodations and the RTW process. Both components required professionals (occupational therapist, RTW coordinator) who were trained about addressing workplace issues and the work organization, in addition to the principles of cognitive-behavioral therapy. The authors of a recent review concluded that there was at best low quality evidence on the effectiveness of workplace interventions for workers with mental health problems [80].

\section{Limitations in Work-Related Mental Health Studies}

Several limitations of the published workplace-related mental health studies must be emphasized. There is a lack of theoretical reasoning as the basis for the proposed interventions, especially in relation to addressing the work environment [78, 87]. The nature of the impairments and work limitations due to $\mathrm{MH}$ conditions were not well described. The concept of "early intervention" that is supported in most musculoskeletal condition-related RTW research has actually led to worse results in at least one mental health-related study, perhaps suggesting that work resumption should be delayed in some instances until significant MH improvement or stabilization has occurred [84]. As related to persistent mental health conditions there is a large discrepancy between psychosocial work factors identified as related to work disability in MH conditions, and the paucity of interventions at the organizational (workplace) level that might actually mitigate these factors.

In the few studies that reported process evaluations, implementation obstacles have included interventions being too complex, delivered too early in the course of the MH condition, or too time-consuming [84, 86]. The risks for the worker with $\mathrm{MH}$ problems of discussing psychosocial work factors with workplace actors are also rarely discussed, which is concerning, given the importance of workplace collaboration emphasized in many RTW interventions [83, 85, 88, 89].

\section{Observations from the Grey Literature}

This literature emphasizes that interventions often are delayed until it is too late to exert any lasting effect, key stakeholders are left out, and different institutions and services tend to work in isolation [73]. Therefore, the 
Table 2 Intervention strategies from the scientific literature to improve outcomes for workers with mental health disorders

\begin{tabular}{|c|c|c|}
\hline Level of intervention & Class of intervention & Examples of intervention \\
\hline \multirow[t]{3}{*}{ Worker level } & Psychological intervention & $\begin{array}{l}\text { Cognitive and/or behavioral therapy } \\
\text { Skills training (stress inoculation training) } \\
\text { Gradual exposure } \\
\text { Problem solving therapy } \\
\text { Occupational therapy } \\
\text { Job coaching }\end{array}$ \\
\hline & Physical intervention & $\begin{array}{l}\text { Relaxation training } \\
\text { Exercise }\end{array}$ \\
\hline & Pharmacological intervention & Medication \\
\hline \multirow[t]{3}{*}{ Workplace level } & Altering material conditions & $\begin{array}{l}\text { Reduce physical exposures } \\
\text { Reduce chemical exposures }\end{array}$ \\
\hline & Altering work schedules & $\begin{array}{l}\text { Working hours } \\
\text { Working shifts } \\
\text { Work intensity } \\
\text { Work pace and deadlines } \\
\text { Rest breaks }\end{array}$ \\
\hline & Altering work organization & $\begin{array}{l}\text { Reduce psychological job demands } \\
\text { Reduce problematic social factors } \\
\text { Assess efforts and provide rewards } \\
\text { Adjust responsibilities } \\
\text { Alter processes and procedures } \\
\text { Alter team organization and structure }\end{array}$ \\
\hline \multirow[t]{2}{*}{ Healthcare provider level } & Provide enhanced care & $\begin{array}{l}\text { Strengthen work focus in primary care } \\
\text { Strengthen work focus in psychiatric care } \\
\text { Strengthen role of occupational physician }\end{array}$ \\
\hline & Improve care coordination & $\begin{array}{l}\text { Integrated case management across disciplines } \\
\text { Coordination of care }\end{array}$ \\
\hline
\end{tabular}

For a listing of applicable reference citations, see Table 3
OECD advocates for a shift toward earlier (but not too early), more integrated and front-line interventions, in order to avoid work exclusion of people with mental ill health [73]. Line managers and general practitioners have been identified as best placed to identify work-related issues, to address impacts and implications, and to involve other professionals as necessary [73]. However, they need improved skills to work with employees experiencing mental health challenges, operational guidelines, and better tools to assist them with both identification and triage and referral processes. Anti-stigma policies can create a better environment to address employee concerns and challenges directly [73].

While a number of potential job accommodations are described in the grey literature related to mental health conditions, there are very few investigations of the effects of these work adjustments in the scientific literature. The roles of frontline managers and work organization are studied more often, but the results are also quite limited (Table 4).

\section{Recommendations for Future Studies}

Based on our review, input from the Special Panel and participants of the Hopkinton conference, several key research priorities emerge. There are some questions that may appear to be unique to specific chronic conditions, but upon careful consideration, many of these issues are variations of the major research needs we identified. For example, the observed variability of work disability factors across age cohorts parallels the variability within a single diagnostic category. However, there is still not sufficient evidence to conclude that all key principles of workplacecentered work disability prevention apply equally across all conditions, as a few studies suggest otherwise [90].

1. Identifying mechanisms in the RTW process Research should identify the mechanisms of a successful RTW process in the workplace, for those with chronic illnesses, across the lifespan, and develop robust theoretical models that guide workplace interventions. There is already a start with research that has identified the characteristics of 
Table 3 Conclusions of systematic reviews of the scientific literature concerning mental health and work outcomes

\begin{tabular}{|c|c|c|}
\hline References & Description & Primary conclusions \\
\hline Furlan et al. [79] & $\begin{array}{l}\text { Review of intervention practices for depression } \\
\text { in the workplace }\end{array}$ & $\begin{array}{l}\text { Evidence was graded as "very low" for all outcomes identified; therefore, } \\
\text { no interventions were recommended }\end{array}$ \\
\hline $\begin{array}{l}\text { Nieuwenhuijsen } \\
\text { et al. [80] }\end{array}$ & $\begin{array}{l}\text { Review of interventions to improve return-to- } \\
\text { work (RTW) after depression }\end{array}$ & $\begin{array}{l}\text { Moderate quality evidence that adding a work-directed intervention to } \\
\text { clinical intervention reduces number of days on sick leave; moderate } \\
\text { quality evidence that enhancing primary or occupational care with } \\
\text { cognitive behavioral therapy reduces days on sick leave }\end{array}$ \\
\hline $\begin{array}{l}\text { Arends et al. } \\
\text { [94] }\end{array}$ & $\begin{array}{l}\text { Review of interventions to facilitate RTW after } \\
\text { adjustment disorders }\end{array}$ & $\begin{array}{l}\text { No randomized controlled trials (RCTs) were found of employee } \\
\text { assistance programs; Eight studies focused on the work environment; } \\
\text { moderate-quality evidence that problem solving therapy significantly } \\
\text { enhanced partial RTW at one-year follow-up }\end{array}$ \\
\hline $\begin{array}{l}\text { Montano et al. } \\
\text { [95] }\end{array}$ & $\begin{array}{l}\text { Review of effects of organizational-level } \\
\text { interventions at work on employee health }\end{array}$ & $\begin{array}{l}\text { Success rates were higher among more comprehensive interventions } \\
\text { tackling material, organizational and work-time related conditions } \\
\text { simultaneously }\end{array}$ \\
\hline Bhui et al. [96] & $\begin{array}{l}\text { Review of ways to manage stress at work (A } \\
\text { summary of existing reviews reporting on } \\
\text { anxiety, depression, and absenteeism) }\end{array}$ & $\begin{array}{l}\text { Individual interventions had a greater effect size for individual-level } \\
\text { outcomes; there was mixed evidence on the effectiveness of } \\
\text { organizational interventions on absenteeism; there was clear evidence } \\
\text { that employer-based physical activity promotion has a small effect on } \\
\text { total absenteeism; Some interventions paradoxically led to deterioration } \\
\text { in mental health and absenteeism }\end{array}$ \\
\hline $\begin{array}{l}\text { Kuoppala et al. } \\
\text { [97] }\end{array}$ & $\begin{array}{l}\text { Review of evidence for workplace health } \\
\text { promotion on job well-being, work ability, and } \\
\text { absenteeism }\end{array}$ & $\begin{array}{l}\text { Sickness absence is reduced by activities promoting healthy lifestyle and } \\
\text { ergonomics }\end{array}$ \\
\hline $\begin{array}{l}\text { Lamontagne } \\
\text { et al. [98] }\end{array}$ & $\begin{array}{l}\text { Review of the evidence supporting job stress } \\
\text { interventions }\end{array}$ & $\begin{array}{l}\text { Individual-focused approaches are effective at the individual level, but } \\
\text { these interventions have no measurable impact at the organizational } \\
\text { level }\end{array}$ \\
\hline Odeen et al. [99] & $\begin{array}{l}\text { Review of active workplace interventions to } \\
\text { reduce sickness absence }\end{array}$ & $\begin{array}{l}\text { One early intervention in employees with mild to severe depressive } \\
\text { complaints and high risk of future long-term sickness absence proved to } \\
\text { be effective in preventing/reducing both sickness absence and } \\
\text { depressive complaints }\end{array}$ \\
\hline Murta et al. [87] & $\begin{array}{l}\text { Review of process evaluations in job stress } \\
\text { management programs }\end{array}$ & $\begin{array}{l}\text { Fewer than half of studies linked process evaluation to outcome } \\
\text { evaluation; process relevant variables were recruitment, intervention } \\
\text { dose received, participants' attitudes toward intervention, and program } \\
\text { reach }\end{array}$ \\
\hline
\end{tabular}

success in workers with chronic health conditions who maintain employment, as well as studies using logic modelling (such as intervention mapping), and other methods to identify the process and systems of successful RTW processes or interventions. But current investigations do not address the challenges of persons with specific chronic conditions or workers across the lifespan. Workplace stakeholders should be involved from the outset in defining the problem and developing solutions.

2. Identifying those at greatest risk of disability We need research on how to effectively and efficiently identify workers with chronic illness, who are at risk for WD, addressing workers across the whole lifecourse, applicable to multiple conditions. This should consider not only workplace and individual factors, but also the influence of socioeconomic inequality, gender issues, and other factors that are relevant. And a longitudinal view is importantnot only work disability prevention, initial return to work, but also maintaining work, quality of work life, and career progression as important outcomes in both young and older workers.

3. Identifying possibilities for work accommodation and support We need research to identify the accommodations and other workplace supports that lead to optimal WDP outcomes, and whether and how the most effective interventions differ by condition. Rather than relying on standardized, diagnosis -based interventions, there is an overarching need to insure that more interventions are individually-directed, worker-centered and workplace-focused, rather than proscriptive and externally generated.

4. Determining appropriate strategies Studies should determine whether different strategies are needed for chronic health conditions that are less visible, episodic, variable in impact, or highly influenced by comorbidity. The focus should be on conditions where symptoms or work impact are less visible and apparent to others, health conditions (such as rheumatoid arthritis or bipolar disorder) or symptoms that are episodic and affect work, or 
Table 4 Sample recommendations (grey literature) for workplace approaches to reducing mental health absenteeism

Source Recommendation

American College of Occupational and

Environmental Medicine [100]

American College of Occupational and

Environmental Medicine [9]

Job Accommodation Network [101]

O’Day [102]

Waddell et al. [103]

Organization for Economic Cooperation and Development [104]

Organisation for Economic Cooperation and Development [104]
Use comprehensive approaches that span injury prevention, health promotion, and accommodation

Provide primary prevention through mental health and resilience promotion

Identify and modify sources of stress and other relevant risk factors, reduce stigma

Provide employee education, voluntary screening, supervisor training, and employee assistance programs

Facilitate early detection and treatment before sickness absence or job loss occurs

Establish referral pathways to find evidence-based practitioners experienced in workplace issues

Provide workplace accommodations for disability prevention and return to work

Engage on-site medical personnel to actively support treatment adherence

Ensure management commitment to an integrated workplace approach for dealing with depression

Evaluate programs periodically for most effective coordination of mental health problems

Ensure that medical determinations of ability to work are based on accurate job information

Recognize potential negative life impacts of a prolonged work absence

Early disability prevention efforts are best

Educate employees about the benefits of an early return to work

Insure appropriate medical treatment of mental health conditions

Give practical guidance on workplace accommodations to address specific functional problems at work

Suggest potential accommodations for a range of mental conditions and provide case example illustrations

Use evidence-based Supported Employment (SE) for people with serious mental illnesses

Provide a reasonably supportive workplace with flexibility and empathy

Become involved in community efforts to provide accommodations for persons with mental health problems

EAP programs may help to reduce mental-health related work disability

Use disease and case management, disability management, and early contact and improved communication

Provide routine occupational health consultations at the workplace for employees with mental health disorders

Address mental health stigma

Manager training and support to respond to workers' mental health issues, including toolkits

Human resource professionals who provide education and support to managers about the RTW process

Avoid high levels of job stress

Provide early response to sick leave

Adopt strategies to avoid workplace conflicts and reduce stigma

Insist on being an active part of a workers' rehabilitation plan to achieve a sustained return to work

Ensure adequate manager support and positive reinforcement

Modified duty or partial sick leave may be an effective strategy to prevent total work absence 
Table 4 continued

\begin{tabular}{ll}
\hline Source & Recommendation \\
\hline World Health Organization [105] & Increase general employee awareness of mental health issues \\
& Support employees at risk \\
& Provide early access to treatment for employees with mental health \\
problems & Reintegrate employees with a mental health problem into the workplace \\
& Effective accommodation should include supervisor orientation, modified \\
& work times, and co-worker support \\
& Potentially useful accommodations are flexible working hours, education, \\
using selected co-workers as mentors & Protect confidentiality \\
Change job content
\end{tabular}

conditions that have a variable and sometimes unpredictable impact on work ability. Comorbidity effects are just starting to be appreciated, yet there are not effective workplace strategies to address their impact on WD. Cancer has a potentially unique situation in that chemotherapy leads to side-effects that can last for a long time, are often under-recognized by workers and their employers,- - especially if the appearance of these side-effects is delayed for several years after a 'cure' has been achieved. This could be a significant opportunity for condition-specific education of supervisors and employers.

5. Greater focus on work retention and sustainability For most chronic health conditions, there is a need for greater focus on work retention/sustainability and career development and progression. Most studies have focused on the individual alone, but more interventions are needed that address work conditions, integrating a proactive approach to vocational adjustment. For post-retirement workers, understanding their career status, financial status, and how this relates to WDP interventions may be particularly important.

6. Incorporating workplace (organizational) solutions Rather than focusing on the worker alone, workplace WDP studies should also address workplace climate, attitudes, responses and readiness for change in relation to WDP chronic health conditions, even though these interventions will be more costly and time-consuming at the outset. Studies should specifically target new ways to enhance supportive environments through co-worker and supervisor training and education of organizational leadership about the challenges of work participation with chronic illness. Emerging studies are addressing workplace policies and practices, making an economic case for broader programs that improve workplace health and safety [91]. Parallel evaluations should address employment of persons with chronic health conditions affecting their ability to work.
7. Recognition of stigma as a potential obstacle to work participation Research should address the importance of stigma as an obstacle to work participation. We should learn more about the factors that lead to both overt and covert (subtle) work discrimination, and develop primary and secondary prevention approaches for this problem in relation to chronic health conditions. Although this is primarily considered with mental health conditions, it is likely to interfere with WDP in other conditions as well, particularly with conditions that are relatively new to the workplace such as early onset dementia, autoimmune disease in young persons, chronic HIV infection.

8. Considering the broader health care and work disability systems For chronic health conditions, workplace interventions need to be articulated within the broader healthcare and disability systems. Increased emphasis should be placed on integrated and sustainable involvement among employer, worker and health care providers. Investigation in some contexts and the Special Panel suggest the potential value of developing and testing a stepped care approach to WD in the workplace — where an initial simple workplace intervention is followed by a sequence of more intensive interventions if the initial approach is not successful [42].

9. Clarifying responsibilities From a public policy point of view, there is a need for greater clarification of the responsibilities of all primary actors and that financial incentives are clearly aligned to achieve desired outcomes [73]. Research studies could be designed to incorporate multiple stakeholders in data collection of potential risk factors or in the development and testing of new intervention strategies.

\section{Avenues for Future Studies}

The overview of the scientific and the grey literature also provided an opportunity to identify important avenues for 
future studies. Early screening by frontline actors (managers, general practitioners, and occupational physicians) should be developed and linked with appropriate (stepped and/or integrated) care. Frontline managers in the workplace should receive training and support in this respect, both for screening and accommodating workers. The effectiveness of job accommodation / work (re)organization strategies proposed in the grey literature should be evaluated. Eventually, these efforts should be integrated with usual mental health care and medical case management services to offer a more seamless intervention for workers.

\section{Conclusions}

There are general principles of effective workplace WDP strategies that are consistent across chronic health conditions, and less information suggesting that there may be condition-specific differences in the most effective strategies. Many chronic conditions are not readily visible, variable in the associated symptoms and impact on work ability, result in stigma upon disclosure, and can lead to discrimination in the workplace, based on a specific diagnosis. At present, these factors limit the ability of employers to effectively accommodate, support, and maintain employment of affected workers. Studies of workers with chronic conditions who are able to maintain employment suggest that work organizational response, self-determined accommodations, work flexibility, and consistent supervisor and manager support are key to their success.

After reviewing the existing scientific literature on WDP, chronic health conditions, and work disability across the working life course, we have found remarkably little research to guide WDP practice. We did not address young workers with health conditions in depth, other chronic conditions (e.g., cardiovascular, infectious, metabolic, neurologic, and cognitive conditions), as we wanted to provide a few examples that would illustrate both differences and similarities. Although there may be important unique features for a particular condition that relate to WDP interventions (e.g., types of symptoms and specific functional limitations), our overall conclusion is that the basic principles of effective workplace-based WDP are most important.

Although the scientific and grey literatures tend to focus on personal determinants and diagnoses, and easily-implemented accommodations, there is ample evidence for the importance of organizational factors across many of these special situations. More broad recognition of the importance of work organizational responses, as opposed to greater clinical focus, is needed to better address WD prevention. Work organizational factors are occasionally emphasized in the grey literature, but are poorly represented in research; given their importance in solving WD problems, this is a priority for these special populations. For example, in what ways do specific organizational issues present a unique challenge for workers with a particular condition (such as cancer), and how can this be overcome? And, how do new work organizational structures, such as temporary, lone work and virtual work present unique challenges or opportunities for WDP for specific conditions or stages of the working lifecourse? Studies on supervisor response, informal and effective accommodations, and how best to address variable conditions and resulting fluctuations in work ability appear to be a priority. For the small employer, a challenge is finding and providing problem-solving resources that can be appropriately specific to a particular condition and work arrangement, for a relatively rare occurrence (work disability).

As more workers with chronic illness seek sustained employment, there is the potential for employers to face more demands for accommodations, costs related to maintaining employment of these workers, more challenges in figuring out who can work and when, and perhaps less predictability about who can stay employed in the long -term. These trends will lead to broader changes as some organizations will find ways to accommodate a broader range of different challenges. Employers who are able to meet these challenges will have access to a greater range of workers and talent, and may reap benefits in terms of affinity and loyalty.

Acknowledgments The conference that led to this article was supported by the Liberty Mutual Research Institute for Safety. The Hopkinton Conference Working Group on Workplace Disability Prevention includes Benjamin C. Amick III, Johannes R. Anema, Elyssa Besen, Peter Blanck, Cécile R. L. Boot, Ute Bültmann, Chetwyn C. H. Chan, George L. Delclos, Kerstin Ekberg, Mark G. Ehrhart, Jean-Baptiste Fassier, Michael Feuerstein, David Gimeno, Vicki L. Kristman, Steven J. Linton, Chris J. Main, Fehmidah Munir, Michael K. Nicholas, Glenn Pransky, William S. Shaw, Michael J. Sullivan, Lois E. Tetrick, Torill H. Tveito, Eira Viikari-Juntura, Kelly Williams-Whitt, and Amanda E. Young.

\section{Compliance with Ethical Standards}

Conflict of interest Glenn Pransky, Elyssa Besen, Peter Blanck, Kirsten Ekberg, Jean-Baptise Fassier, Michael Feuerstein, and Fehmidah Munir declare that they have no conflict of interest.

Ethical approval This article does not contain any studies with human participants or animals performed by any of the authors.

Open Access This article is distributed under the terms of the Creative Commons Attribution 4.0 International License (http://crea tivecommons.org/licenses/by/4.0/), which permits unrestricted use, distribution, and reproduction in any medium, provided you give appropriate credit to the original author(s) and the source, provide a link to the Creative Commons license, and indicate if changes were made. 


\section{References}

1. Toossi M. Labor force projections to 2020: a more slowly growing workforce. Mon Labor Rev. 2012;135:43-64.

2. Leijten FR, Van Den Heuvel SG, Ybema JF, Van Der Beek AJ, Robroek SJ, Burdorf A. The influence of chronic health problems on work ability and productivity at work: a longitudinal study among older employees. Scand J Work Environ Health. 2014;40:473-82.

3. Settersten RA. Time, age, and the transition to retirement: new evidence on life-course flexibility? Int J Aging Hum Dev. 1998;47:177-203.

4. Bloom DE, Cafiero ET, Jané-Llopis E, Abrahams-Gessel S, Bloom L, Fathima S, et al. The global economic burden of noncommunicable diseases. Geneva: World Economic Forum; 2011.

5. Blanck P. The struggle for web eQuality by persons with cognitive disabilities. Behav Sci Law. 2014;32:4-32.

6. Loisel P, Buchbinder R, Hazard R, Keller R, Scheel I, Van Tulder M, et al. Prevention of work disability due to musculoskeletal disorders: the challenge of implementing evidence. J Occup Rehabil. 2005;15:507-24.

7. Blonk RW, Brenninkmeijer V, Lagerveld SE, Houtman IL. Return to work: a comparison of two cognitive behavioural interventions in cases of work-related psychological complaints among the self-employed. Work Stress. 2006;20:129-44.

8. Shaw WS, Main CJ, Nicholas MK, Linton SJ, Anema JR, Pransky G et al (2016) Employer policies and practices to manage and prevent disability: forward to the special issue. J Occup Rehabil. 2016. doi:10.1007/s10926-016-9658-x.

9. American College of Occupational and Environmental Medicine. Guidelines for preventing needless work disability by helping people stay employed. Elk Grove Village: American College of Occupational and Environmental Medicine; 2006.

10. Silverstein M. Meeting the challenges of an aging workforce. Am J Ind Med. 2008;51:269-80.

11. United Nations. World population ageing 2013. New York: Department of Economic and Social Affairs Population Division; 2013.

12. Factbook OECDOECD. Economic, environment, and social statistics. Paris: OECD Publishing; 2014. p. 2014.

13. Commission of the European Communities. Increasing the employment of older workers and delaying the exit from the labour market. Brussels; 2004.

14. Berecki-Gisolf J, Clay FJ, Collie A, Mcclure RJ. The impact of aging on work disability and return to work: insights from workers' compensation claim records. J Occup Environ Med. 2012;54:318-27.

15. Burton WN, Pransky G, Conti DJ, Chen C-Y, Edington DW. The association of medical conditions and presenteeism. J Occup Environ Med. 2004;46:S38-45.

16. Bruffaerts R, Vilagut G, Demyttenaere K, Alonso J, Alhamzawi A, Andrade LH, et al. Role of common mental and physical disorders in partial disability around the world. Br J Psychiatry. 2012;200:454-61.

17. Fried V, Bernstein A, Bush M. Multiple chronic conditions among adults aged 45 and older: trends over the past 10 years. Washington: Department of Health and Human Services; 2012.

18. Ervasti J, Vahtera J, Virtanen P, Pentti J, Oksanen T, Ahola K, et al. Is temporary employment a risk factor for work disability due to depressive disorders and delayed return to work? The Finnish Public Sector Study. Scand J Work Environ Health. 2014;40:343-52.

19. Varekamp I, De Vries G, Heutink A, Van Dijk FJ. Empowering employees with chronic diseases; development of an intervention aimed at job retention and design of a randomised controlled trial. BMC Health Serv Res. 2008;8:224.

20. Carls GS, Roebuck MC, Brennan TA, Slezak JA, Matlin OS, Gibson TB. Impact of medication adherence on absenteeism and short-term disability for five chronic diseases. J Occup Environ Med. 2012;54:792-805.

21. Restrepo T, Shuford H. Workers compensation and the aging workforce. Boca Raton, FL: NCCI Research Brief; 2011.

22. Biddle J, Boden LI, Reville RT. Older workers face more serious consequences from workplace injuries. Washington, DC: National Academy of Social Insurance; 2003.

23. Towers Watson. Pathway to health and productivity: 2011/2012 Staying@Work survey report. Washington, DC: National Business Group on Health; 2012.

24. Shaw WS, Robertson MM, Pransky G, Mclellan RK. Employee perspectives on the role of supervisors to prevent workplace disability after injuries. J Occup Rehabil. 2003;13:129-42.

25. Hadler NM. Workers with disabling back pain. N Engl J Med. 1997;337:341-3.

26. Proper K, Van Der Beek A, Hildebrandt V, Twisk J, Van Mechelen W. Worksite health promotion using individual counselling and the effectiveness on sick leave; results of a randomised controlled trial. Occup Environ Med. 2004;61:275-9.

27. Brox J, Frøystein O. Health-related quality of life and sickness absence in community nursing home employees: randomized controlled trial of physical exercise. Occup Med. 2005;55:558-63.

28. Van Dongen JM, Strijk JE, Proper KI, Van Wier MF, Van Mechelen W, Van Tulder MW, et al. A cost-effectiveness and return-on-investment analysis of a worksite vitality intervention among older hospital workers: results of a randomized controlled trial. J Occup Environ Med. 2013;55:337-46.

29. Siukola A, Virtanen P, Huhtala H, Nygård C-H. Absenteeism following a workplace intervention for older food industry workers. Occup Med. 2011;61:583-5.

30. Palumbo MV, Wu G, Shaner-Mcrae H, Rambur B, Mcintosh B. Tai Chi for older nurses: a workplace wellness pilot study. Appl Nurs Res. 2012;25:54-9.

31. Jutkowitz E, Nyman JA, Michaud TL, Abraham JM, Dowd B. For what illnesses is a disease management program most effective? J Occup Environ Med. 2015;57:117-23.

32. Melton L, Anfield R, Kane G, White N, Young J, Dunnington K. Reducing the incidence of short-term disability: testing the effectiveness of an absence prediction and prevention intervention using an experimental design. J Occup Environ Med. 2012;54:1441-6.

33. Genovese S, Tedeschi D. Effects of vildagliptin/metformin therapy on patient-reported outcomes: work productivity, patient satisfaction, and resource utilization. Adv Ther. 2013;30:152-64.

34. Kant I, Jansen NW, Van Amelsvoort LG, Van Leusden R, Berkouwer A. Structured early consultation with the occupational physician reduces sickness absence among office workers at high risk for long-term sickness absence: a randomized controlled trial. J Occup Rehabil. 2008;18:79-86.

35. Wolf AM, Siadaty MS, Crowther JQ, Nadler JL, Wagner DL, Cavalieri SL, et al. Impact of lifestyle intervention on lost productivity and disability: improving control with activity and nutrition (ICAN). J Occup Environ Med. 2009;51:139.

36. Taimela S, Malmivaara A, Justen S, Läärä E, Sintonen H, Tiekso J, et al. The effectiveness of two occupational health intervention programmes in reducing sickness absence among employees at risk. Two randomised controlled trials. Occup Environ Med. 2008;65:236-41. 
37. Tveito TH, Shaw WS, Huang Y-H, Nicholas M, Wagner G. Managing pain in the workplace: a focus group study of challenges, strategies and what matters most to workers with low back pain. Disabil Rehabil. 2010;32:2035-45.

38. De Vries HJ, Brouwer S, Groothoff JW, Geertzen JH, Reneman MF. Staying at work with chronic nonspecific musculoskeletal pain: a qualitative study of workers' experiences. BMC Musculoskelet Disord. 2011;12:1.

39. Munir F, Randall R, Yarker J, Nielsen K. The influence of employer support on employee management of chronic health conditions at work. J Occup Rehabil. 2009;19:333-44.

40. Haafkens JA, Kopnina H, Meerman MG, Van Dijk FJ. Facilitating job retention for chronically ill employees: perspectives of line managers and human resource managers. BMC Health Serv Res. 2011;11:1.

41. Hutting N, Staal JB, Engels JA, Heerkens YF, Detaille SI, Nijhuis-Van Der Sanden MW. Effect evaluation of a self-management programme for employees with complaints of the arm, neck or shoulder: a randomised controlled trial. Occup Environ Med. 2015;72:852-61.

42. Werner EL, Lærum E, Wormgoor ME, Lindh E, Indahl A. Peer support in an occupational setting preventing LBP-related sick leave. Occup Med. 2007;57:590-5.

43. Boot CR, Van Den Heuvel SG, Bültmann U, De Boer AG, Koppes LL, Van Der Beek AJ. Work adjustments in a representative sample of employees with a chronic disease in the Netherlands. J Occup Rehabil. 2013;23:200-8.

44. Scott-Parker S. Delivering business improvement by managing workplace adjustments as a core business process. London, UK: Business Disability-Smart Organizations; 2014.

45. Karlson B, Jönsson P, Österberg K. Long-term stability of return to work after a workplace-oriented intervention for patients on sick leave for burnout. BMC Public Health. 2014;14:1.

46. Steenstra I, Knol D, Bongers P, Anema J, Van Mechelen W, De Vet H. What works best for whom? An exploratory, subgroup analysis in a randomized, controlled trial on the effectiveness of a workplace intervention in low back pain patients on return to work. Spine. 2009;34:1243-9.

47. Globocan. World estimated cancer incidence by age. International Agency for Research on Cancer. 2012 http://globocan. iarc.fr/old/age-specific_table_r.asp?selection $=224900 \&$ title $=$ World $\&$ se $=0 \&$ type $=0 \&$ stat $=0 \&$ window $=1 \&$ sort $=0 \&$ submit $=\% \mathrm{C} 2 \%$ A0Execute. Accessed 1 Sep 2015.

48. Mehnert A. Employment and work-related issues in cancer survivors. Crit Rev Oncol Hematol. 2011;77:109-30.

49. Taskila T, Lindbohm M. Factors affecting cancer survivors' employment and work ability. Acta Oncol. 2007;46:446-51.

50. Thielen K, Kolodziejczyk C, Andersen I, Heinesen E, Diderichsen F. Cancer stage, comorbidity, and socioeconomic differences in the effect of cancer on labour market participation: a danish register-based follow-up study. PLoS One. 2015; 10:e0128621.

51. Pryce J, Munir F, Haslam C. Cancer survivorship and work: symptoms, supervisor response, co-worker disclosure and work adjustment. J Occup Rehabil. 2007;17:83-92.

52. Amidi A, Christensen S, Mehlsen M, Jensen A, Pedersen A, Zachariae R. Long-term subjective cognitive functioning following adjuvant systemic treatment: 7-9 years follow-up of a nationwide cohort of women treated for primary breast cancer. Br J Cancer. 2015;113:794-801.

53. Mehnert A, De Boer A, Feuerstein M. Employment challenges for cancer survivors. Cancer. 2013;119:2151-9.

54. De Boer AG, Taskila T, Ojajärvi A, Van Dijk FJ, Verbeek JH. Cancer survivors and unemployment: a meta-analysis and metaregression. J Am Med Assoc. 2009;301:753-62.
55. Chaker L, Falla A, Van Der Lee SJ, Muka T, Imo D, Jaspers L, et al. The global impact of non-communicable diseases on macro-economic productivity: a systematic review. Eur J Epidemiol. 2015;30:357-95.

56. Duijts SF, Egmond MP, Spelten E, Muijen P, Anema JR, Beek AJ. Physical and psychosocial problems in cancer survivors beyond return to work: a systematic review. Psycho-Oncology. 2014;23:481-92.

57. Bower JE. Behavioral symptoms in patients with breast cancer and survivors. J Clin Oncol. 2008;26:768-77.

58. Torp S, Nielsen RA, Gudbergsson SB, Fosså SD, Dahl AA. Sick leave patterns among 5-year cancer survivors: a registry-based retrospective cohort study. J Cancer Surviv. 2012;6:315-23.

59. Macmillan Cancer Support. Working through cancer: a guide for employers. London, UK; 2010.

60. Midwest Business Group on Health C. Take control cancer screening: cancer awareness resources for employers. http:// www.tcyh.org/employers/employers_cancer.shtml2015.

61. Amir Z, Neary D, Luker K. Cancer survivors' views of work 3 years post diagnosis: a UK perspective. Eur J Oncol Nurs. 2008;12:190-7.

62. Feuerstein M, Luff GM, Harrington CB, Olsen CH. Pattern of workplace disputes in cancer survivors: a population study of ADA claims. J Cancer Surviv. 2007;1:185-92.

63. Bennett JA, Brown P, Cameron L, Whitehead LC, Porter D, Mcpherson KM. Changes in employment and household income during the 24 months following a cancer diagnosis. Support Care Cancer. 2009;17:1057-64.

64. De Boer A, Taskila T, Tamminga S, Frings-Dresen M, Feuerstein M, Verbeek J. Interventions to en-hance return-to-work for cancer patients. Cochrane Database Syst Rev. 2011;16: CD007569.

65. Munir F, Yarker J, Hicks B, Donaldson-Feilder E. Returning employees back to work: developing a measure for supervisors to support return to work (SSRW). J Occup Rehabil. 2012;22:196-208.

66. Munir F, Kalawsky K, Wallis DJ, Donaldson-Feilder E. Using intervention mapping to develop a work-related guidance tool for those affected by cancer. BMC Public Health. 2013;13:1.

67. Stapelfeldt CM, Labriola M, Jensen AB, Andersen NT, Momsen A-MH, Nielsen CV. Municipal return to work management in cancer survivors undergoing cancer treatment: a protocol on a controlled intervention study. BMC Public Health. 2015;15:720.

68. Van Egmond MP, Duijts SF, Vermeulen SJ, Van Der Beek AJ, Anema JR. Return to work in sick-listed cancer survivors with job loss: design of a randomised controlled trial. BMC Cancer. 2015; $15: 1$.

69. Whiteford HA, Degenhardt L, Rehm J, Baxter AJ, Ferrari AJ, Erskine HE, et al. Global burden of disease attributable to mental and substance use disorders: findings from the Global Burden of Disease Study 2010. Lancet. 2013;382:1575-86.

70. Office of Economic Co-Operation and Development. Fit mind, Fit job. From evidence to practice in mental health and work. Paris: Office of Economic Co-Operation and Development; 2015.

71. Kessler RC, Merikangas KR, Wang PS. The prevalence and correlates of workplace depression in the national comorbidity survey replication. Jour Occ Env Med. 2008;50:381-90.

72. O' Day B, Blyler C, Collins A, Fischer B, Gill C, Honeycutt T, et al. Improving employment outcomes for people with psychiatric disorders and other disabilities. Washington: US Department of Health and Human Services; 2014.

73. Dorner TE, Alexanderson K, Svedberg P, Tinghog P, Ropponen A, Mittendorfer-Rutz E. Synergistic effect between back pain and common mental disorders and the risk of future disability 
pension: a nationwide study from Sweden. Psychol Med. 2015;46:1-12.

74. Waddell G, Burton AK. Is work good for your health and wellbeing?. London: The Stationery Office; 2006.

75. Stansfeld S, Candy B. Psychosocial work environment and mental health - a meta-analytic review. Scand J Work Environ Health. 2006;32:443-62.

76. Niedhammer I, Chastang JF, Sultan-Taieb H, Vermeylen G, Parent-Thirion A. Psychosocial work factors and sickness absence in 31 countries in Europe. Eur $\mathbf{J}$ Public Health. 2013;23:622-9.

77. Bhui KS, Dinos S, Stansfeld SA, White PD. A synthesis of the evidence for managing stress at work: a review of the reviews reporting on anxiety, depression, and absenteeism. J Environ Public Health. 2012;2012:515874.

78. Martin A, Sanderson K, Cocker F. Meta-analysis of the effects of health promotion intervention in the workplace on depression and anxiety symptoms. Scand J Work Environ Health. 2009;35:7-18.

79. Furlan AD, Gnam WH, Carnide N, Irvin E, Amick BC 3rd, Derango K, et al. Systematic review of intervention practices for depression in the workplace. J Occup Rehabil. 2012;22:312-21.

80. Nieuwenhuijsen K, Faber B, Verbeek JH, Neumeyer-Gromen A, Hees HL, Verhoeven AC, et al. Interventions to improve return to work in depressed people. Cochrane Database Syst Rev. 2014;12:CD006237.

81. Van Vilsteren M, Van Oostrom SH, De Vet HC, Franche RL, Boot CR, Anema JR. Workplace interventions to prevent work disability in workers on sick leave. Cochrane Database Syst Rev. 2015;10:Cd006955.

82. Hees HL, De Vries G, Koeter MW, Schene AH. Adjuvant occupational therapy improves long-term depression recovery and return-to-work in good health in sick-listed employees with major depression: results of a randomised controlled trial. Occup Environ Med. 2012;70:252-60.

83. Noordik E, Van Der Klink JJ, Geskus RB, De Boer MR, Van Dijk FJ, Nieuwenhuijsen K. Effectiveness of an exposure-based return-to-work program for workers on sick leave due to common mental disorders: a cluster-randomized controlled trial. Scand J Work Environ Health. 2013;39:144-54.

84. Van Oostrom SH, Van Mechelen W, Terluin B, De Vet HC, Knol DL, Anema JR. A workplace intervention for sick-listed employees with distress: results of a randomised controlled trial. Occup Environ Med. 2010;67:596-602.

85. Vlasveld MC, Van Der Feltz-Cornelis CM, Ader HJ, Anema JR, Hoedeman R, Van Mechelen W, et al. Collaborative care for sick-listed workers with major depressive disorder: a randomised controlled trial from the Netherlands Depression Initiative aimed at return to work and depressive symptoms. Occup Environ Med. 2013;70:223-30.

86. Martin A, Karanika-Murray M, Biron C, Sanderson K. The psychosocial work environment, employee mental health and organizational interventions: improving research and practice by taking a multilevel approach. Stress Health. 2016;32:201-15.

87. Murta SG, Sanderson K, Oldenburg B. Process evaluation in occupational stress management programs: a systematic review. Am J Health Promot. 2007;21:248-54.

88. Vlasveld MC, Anema JR, Beekman AT, Van Mechelen W, Hoedeman R, Van Marwijk HW, et al. Multidisciplinary collaborative care for depressive disorder in the occupational health setting: design of a randomised controlled trial and cost-effectiveness study. BMC Health Serv Res. 2008;8:99.
89. Boot CR, De Kruif AT, Shaw WS, Van Der Beek AJ, Deeg DJ, Abma T. Factors important for work participation among older workers with depression, cardiovascular disease, and osteoarthritis: a mixed method study. J Occup Rehabil. 2016;26:160-72.

90. Fabius R, Thayer RD, Konicki DL, Yarborough CM, Peterson $\mathrm{KW}$, Isaac F, et al. The link between workforce health and safety and the health of the bottom line: tracking market performance of companies that nurture a "culture of health". J Occup Environ Med. 2013;55:993-1000.

91. Chow SL, Ting AS, Su TT. Development of conceptual framework to understand factors associated with return to work among cancer survivors: a systematic review. Iran J Public Health. 2014;43:391.

92. Feuerstein M, Todd BL, Moskowitz MC, Bruns GL, Stoler MR, Nassif T, Yu X. Work in cancer survivors: a model for practice and research. J Cancer Surviv. 2010;4(4):415-37.

93. Steiner JF, Cavender TA, Main DS, Bradley CJ. Assessing the impact of cancer on work outcomes: what are the research needs? Cancer. 2004;101(8):1703-11.

94. Arends I, Bruinvels DJ, Rebergen DS, Nieuwenhuijsen K, Madan I, Neumeyer-Gromen A, Bültmann U, Verbeek JH. Interventions to facilitate return to work in adults with adjustment disorders. Cochrane Database Syst Rev. 2012;12:006389.

95. Montano D, Hoven H, Siegrist J. Effects of organisational-level interventions at work on employees' health: a systematic review. BMC Public Health. 2014;14:135.

96. Bhui KS, Dinos S, Stansfeld SA, White PD. A synthesis of the evidence for managing stress at work: a review of the reviews reporting on anxiety, depression, and absenteeism. J Environ Public Health. 2012;2012:515874.

97. Kuoppala J, Lamminpää A, Husman P. Work health promotion, job well-being, and sickness absences-a systematic review and meta-analysis. J Occup Environ Med. 2008;50:1216-27.

98. Lamontagne AD, Keegel T, Louie AM, Ostry A, Landsbergis PA. A systematic review of the job-stress intervention evaluation literature, 1990-2005. Int J Occup Environ Health. 2007;13:268-80.

99. Odeen M, Magnussen LH, Maeland S, Larun L, Eriksen HR, Tveito TH. Systematic review of active workplace interventions to reduce sickness absence. Occup Med (Lond). 2013;63:7-16.

100. American College of Occupational and Environmental Medicine. Depression in the working population. Elk Grove Village: American College of Occupational and Environmental Medicine; 2009.

101. Job Acommodation Network. Employees with Mental Health Impairments. http://askjan.org/media/depr.htm. Job Accommodation Network; 2014.

102. O'day B, Blyler C, Collins A, Fischer B, Gill C, Honeycutt T, et al. Improving employment outcomes for people with psychiatric disorders and other disabilities. Washington: US Department of Health and Human Services; 2014.

103. Waddell G, Burton AK, Kendall N. Vocational rehabilitation: what works, for whom, and when?. London: Department for Work and Pensions; 2013.

104. Organization for Economic Co-Operation and Development. Sick on the job? Myths and realities about mental health and work. Paris: OECD Publishing; 2012.

105. World Health Organization. Mental health policies and programs in the workplace. Geneva: World Health Organization; 2005. 